\title{
Prognostic Value of Procalcitonin in Adult Patients with Sepsis: A Systematic Review and Meta-Analysis
}

\author{
Dan Liu ${ }^{1,2,3 \odot}$, Longxiang Su ${ }^{4 \odot}$, Gencheng Han ${ }^{5}$, Peng Yan ${ }^{1}$, Lixin Xie ${ }^{1 *}$ \\ 1 Department of Pulmonary \& Critical Care Medicine, Chinese PLA General Hospital, 28 Fuxing Road, \\ Beijing, 100853, China, 2 Medical School, Nankai University, 94 Weijin Road, Tianjin, 300071, China, \\ 3 Department of Respiratory Medicine, Tianjin Medical University General Hospital, Tianjin, 300070, China, \\ 4 Department of Critical Care Medicine, Peking Union Medical College Hospital, Peking Union Medical \\ College \& Chinese Academy of Medical Sciences, Beijing, 100005, China, 5 Laboratory of Immunology, \\ Institute of Basic Medical Sciences, Beijing, 100850, China \\ - These authors contributed equally to this work. \\ *xielx@263.net
}

\section{G openaccess}

Citation: Liu D, Su L, Han G, Yan P, Xie L (2015) Prognostic Value of Procalcitonin in Adult Patients with Sepsis: A Systematic Review and Meta-Analysis. PLoS ONE 10(6): e0129450. doi:10.1371/journal. pone. 0129450

Academic Editor: Cordula M. Stover, University of Leicester, UNITED KINGDOM

Received: February 2, 2015

Accepted: May 9, 2015

Published: June 15, 2015

Copyright: @ 2015 Liu et al. This is an open access article distributed under the terms of the Creative Commons Attribution License, which permits unrestricted use, distribution, and reproduction in any medium, provided the original author and source are credited.

Data Availability Statement: All relevant data are within the paper and its Supporting Information files.

Funding: The authors have no support or funding to report.

Competing Interests: The authors have declared that no competing interests exist.

\section{Abstract}

Procalcitonin (PCT) has been widely investigated for its prognostic value in septic patients. However, studies have produced conflicting results. The purpose of the present meta-analysis is to explore the diagnostic accuracy of a single PCT concentration and PCT non-clearance in predicting all-cause sepsis mortality. We searched PubMed, Embase, Web of Knowledge and the Cochrane Library. Articles written in English were included. A $2 \times 2$ contingency table was constructed based on all-cause mortality and PCT level or PCT nonclearance in septic patients. Two authors independently evaluated study eligibility and extracted data. The diagnostic value of PCT in predicting prognosis was determined using a bivariate meta-analysis model. We used the $\mathrm{Q}$-test and $l^{2}$ index to test heterogeneity. Twenty-three studies with 3,994 patients were included. An elevated PCT level was associated with a higher risk of death. The pooled relative risk (RR) was 2.60 (95\% confidence interval (Cl), 2.05-3.30) using a random-effects model $\left(l^{2}=63.5 \%\right)$. The overall area under the summary receiver operator characteristic (SROC) curve was $0.77(95 \% \mathrm{Cl}, 0.73-0.80)$, with a sensitivity and specificity of $0.76(95 \% \mathrm{Cl}, 0.67-0.82)$ and $0.64(95 \% \mathrm{Cl}, 0.52-0.74)$, respectively. There was significant evidence of heterogeneity for the PCT testing time $(P=0.020)$. Initial PCT values were of limited prognostic value in patients with sepsis. PCT non-clearance was a prognostic factor of death in patients with sepsis. The pooled RR was 3.05 $(95 \% \mathrm{Cl}, 2.35-3.95)$ using a fixed-effects model $\left(I^{2}=37.9 \%\right)$. The overall area under the SROC curve was $0.79(95 \% \mathrm{Cl}, 0.75-0.83)$, with a sensitivity and specificity of $0.72(95 \%$ $\mathrm{Cl}, 0.58-0.82)$ and $0.77(95 \% \mathrm{Cl}, 0.55-0.90)$, respectively. Elevated PCT concentrations and PCT non-clearance are strongly associated with all-cause mortality in septic patients. Further studies are needed to define the optimal cut-off point and the optimal definition of PCT non-clearance for accurate risk assessment. 


\section{Introduction}

Sepsis is a life-threatening condition that arises when the body's response to an infection injures its own tissues and organs [1]. Despite advances in antibiotic therapy and modern life support, the fatality rate of patients with sepsis has remained as high as $30 \%-60 \%$ worldwide [2-3]. Early identification of patients at high risk of dying from sepsis may help initiate rapid and appropriate therapeutic interventions and may have a great impact on sepsis-related morbidity and mortality. However, an accurate assessment of patients at risk for poor clinical outcomes is challenging for clinicians.

Clinical severity scores, such as the Acute Physiology and Chronic Health Evaluation (APACHEII) score and the Sequential Organ Failure Assessment (SOFA) score, have been validated for risk stratification in critical care settings [4-5]. However, clinical severity scoring tools tend to be used more in research and are not widely used in clinical decision-making. In recent years, a growing body of clinical research studies has identified blood biomarkers that may confer additional information to estimate disease progression in sepsis [6-8].

Procalcitonin (PCT), the prehormone of calcitonin, has been widely investigated in infectious diseases. Apart from its diagnostic value, PCT is also of great value for mirroring the severity of infectious diseases, such as pneumonia. In community-acquired pneumonia (CAP), PCT was shown to be a biomarker of poor outcome [9-10]. In patients suffering from ventilator-associated pneumonia (VAP), serum PCT levels could predict death and septic shock [11]. More importantly, some studies have demonstrated that PCT may confer prognostic information in sepsis[10]. An elevated PCT concentrations were reported to be strongly associated with all-cause mortality in septic patients [12]. In addition, patients at high risk of dying may suffered an persistently elevated PCT level. Thus, researches have reported that PCT non-clearance could also predict outcome of sepsis [13]. However, those studies had limited patient numbers, and the conclusions were debated. The aim of this meta-analysis was to systematically and quantitatively evaluate all available publications that assessed the prognostic accuracy of a single PCT concentration and PCT non-clearance in adult patients with sepsis and draw conclusions from these studies.

\section{Materials and Methods}

\section{Search strategy and selection criteria}

We systematically searched studies using PubMed, Embase, Web of Knowledge and the Cochrane Library. The search terms were as follows: (procalcitonin or PCT or "PCT clearance" or "PCT-c" or "PCT decrease" or "PCT kinetics") and (sepsis or septicemia or septicemia or septic) and (mortality or prognosis). We include articles written in English and Spanish. No publication date restrictions were applied for searching. We further reviewed the reference list of the selected articles to obtain potentially relevant articles.

Eligible studies had to have a well-defined reference standard for patients involved (sepsis or severe sepsis or septic shock) according to the criteria of the American College of Chest Physicians/Society of Critical Care Medicine $[14,15]$. PCT non-clearance was defined as an persistently elevated PCT level. For studies evaluated PCT non-clearance associated with prognosis of sepsis, they should measured $\triangle \mathrm{PCT} / \mathrm{PCT}$ baseline, which means the relative changes in PCT - the difference between the subsequent and baseline measurement- to the baseline PCT. Studies also had to involve the collection of single PCT concentrations or PCT non-clearance data as predictors of all-cause mortality in adult ( $>18$ years old) septic patients. Further, a $2 \times 2$ contingency table should be conducted based on those data. If multiple studies reused the same patient sample, the most recent article or the most informative article was included. For studies 
that assessed procalcitonin levels associated with different follow-up periods, we chose the most widely used period among the included studies.

Reviews, letters, commentaries, correspondences, case reports, conference abstracts, expert opinions, editorials and animal experiments were excluded. Articles involving pediatric patients were also excluded. Two investigators (Liu D and Su LX) independently executed the search strategy and evaluated the studies. Any disagreement was resolved by a third reviewer (Xie LX). We performed this meta-analysis according to the Preferred Reporting Items for Meta-Analyses (PRISMA) statement checklist (S1 \& S2 Files). To improve our write-up, we have sent our paper to AJE (American Journal Experts) for edited (S3 File).

\section{Data extraction and quality assessment}

The following descriptive data were extracted from the original studies: the name of the first author, publication year, the country of origin, study design, clinical setting, assay manufacturer, sample size, endpoints, the prevalence of mortality, the proportion of male patients, mean ages, the definition of PCT non-clearance, sepsis severity, cut-off point, true positives (TP), false positives (FP), false negatives (FN), true negatives (TN), sensitivity (SEN) and specificity (SPE). We contacted the corresponding authors of any study that was missing necessary data or that required clarification. We referred to the original Quality Assessment of Diagnostic Accuracy Studies (QUADAS) checklist [16] for diagnostic studies, and we revised several items to make the criteria more useful for our present meta-analysis. We evaluated the following: (1) information bias (i.e., the representativeness of the study sample and clearly described diagnostic criteria for sepsis); (2) selection bias (i.e., the recruitment of consecutive patients); (3) confusion bias (i.e., the blinding of professionals with influence on patient prognosis to PCT level); and (4) confounding bias (i.e., the exclusion of patients with comorbidities potential linked to PCT levels).

\section{Statistical analysis}

Statistical analyses were performed using the MIDAS module in STATA version 12.0 (Stata Corporation, College Station, TX) and Meta-Disc 1.4 (XI Cochrane Colloquium, Barcelona, Spain). A $P$-value of less than 0.05 was considered statistically significant. We tabulated TP, FP, FN, and TN rates based on the effect of single PCT levels or PCT non-clearance on all-cause mortality in sepsis patients. Relative risk (RR) was used to assess the predictive value of PCT, which was pooled according to a fixed-effects or random-effects model based on DerSimonian and Lair's method [17]. Q-test and $I^{2}$ indexes were calculated to assess inter-study heterogeneity [18-19]. Values of $25 \%, 50 \%$ and $75 \%$ for the $I^{2}$ test represented low, medium and high heterogeneity, respectively [20]. $I^{2}$ values of less than $50 \%$ represented acceptable between-study heterogeneity, and the fixed-effects model was selected. Otherwise, the random-effects model was selected. RRs greater than 1 indicated an increased mortality risk from exposure, and RRs less than 1 indicated a beneficial effect.

The presence of a threshold effect on the prognostic accuracy of PCT in sepsis patients was evaluated with the Spearman correlation coefficient between the logits of SEN and SPE. If no threshold effect existed, a bivariate random effects regression model [21-22] was used to calculate the pooled SEN, SPE, diagnostic odds ratio (DOR), positive likelihood ratio (PLR), and negative likelihood ratio (NLR). We also constructed a summary receiver operator characteristic (SROC) curve by plotting the individual and summary points of SEN and SPE to assess the overall diagnostic accuracy [23].

We performed subgroup analyses to explore the prognostic accuracy of PCT when restricted to different clinical settings (emergency department (ED) and intensive care unit (ICU)), 
studies using initial PCT levels, and studies involving patients with severe sepsis and septic shock. A univariate meta-regression analysis was performed to explore the sources of potential heterogeneity between studies. The covariates included in the analysis were as follows: the year of publication, the sample size, the prevalence of mortality, the clinical setting, the assay manufacturer, the procalcitonin testing time, the sampling method (i.e., whether studies recruited patients consecutively), and comorbidities (i.e., whether studies excluded patients with comorbidities potentially linked to PCT levels). Publication bias was tested using Deek's funnel plot.

\section{Results}

Our database search retrieved 2,098 articles. We eliminated 1,963 articles for various reasons based on the title and abstract, leaving 135 studies to scrutinize with a full text review. In total, 23 studies [24-46] fulfilled our eligibility criteria and were finally included (Fig 1). We divided the results of two studies into two parts because investigators reported the diagnostic accuracy separately for two cohorts of patients. Thus, we analyzed 25 datasets. We did not identify any additional relevant articles in the bibliographies of original articles. The characteristics of the included studies are listed in Table 1 and Table 2.

\section{Characteristics of included studies}

The included studies were published from 2000 to 2014. Thirteen studies [24, 27, 28, 30-31, 35-36, 38-39, 42-45] were conducted in Europe, eight [25-26, 29, 32-33, 37, 41, 46] were conducted in Asia, one [40] was conducted in America, and one [34] in was conducted in Australia. With one exception [45], all studies were published in English. The mean age of patients varied between 45 and 75.8 years, and the proportion of men ranged from 44.8 to $70.4 \%$. Twelve studies $[25,27,30-31,34,39-45]$ included only patients with severe sepsis or septic shock. The most frequent source of sepsis was pulmonary infection. Three studies $[26,35,37]$ were performed in EDs, one [38a] was performed in a hospital ward, and the remaining studies were performed in an ICU. With respect to admission category characteristics, three studies $[25,28,33]$ involved only medical patients, two $[34,39]$ involved only surgical patients, and the remaining studies involved both medical and surgical patients. Fifteen studies [24-38] evaluated the effect of single PCT concentrations on all-cause mortality in sepsis patients. Among these studies, three [24,34-35] measured PCT level on the fifth or sixth day after admission and twelve collected blood samples within $24 \mathrm{~h}$ of sepsis diagnosis. Eight studies [39-46] evaluated PCT clearance. Follow-up periods differed across studies, including 28 days [25, 29-33], 30 days [26], ICU stays [24, 28] and in-hospital stays [27].

\section{Study quality and publication bias}

All studies included a representative sample of patients who underwent PCT testing in practice and clearly described the diagnostic criteria for sepsis. Nine studies [25-28, 33, 36, 39-40, 44] included consecutive patients. Three studies $[35,42,46]$ mentioned the blinding of professionals who influenced patient prognosis to PCT level. Four studies [24, 29, 33, 35] excluded patients with comorbidities potentially linked to PCT levels, such as end-organ damage and autoimmune diseases. The Deek's funnel plot of the included studies suggested the presence of publication bias (Fig $2 \mathrm{~A}$ and $2 \mathrm{~B}$ ).

\section{Data synthesis and meta-analysis}

Analysis of the association of PCT concentration with mortality. Sixteen studies [2438] with 3126 patients were included in this group. All studies showed that an elevated PCT 


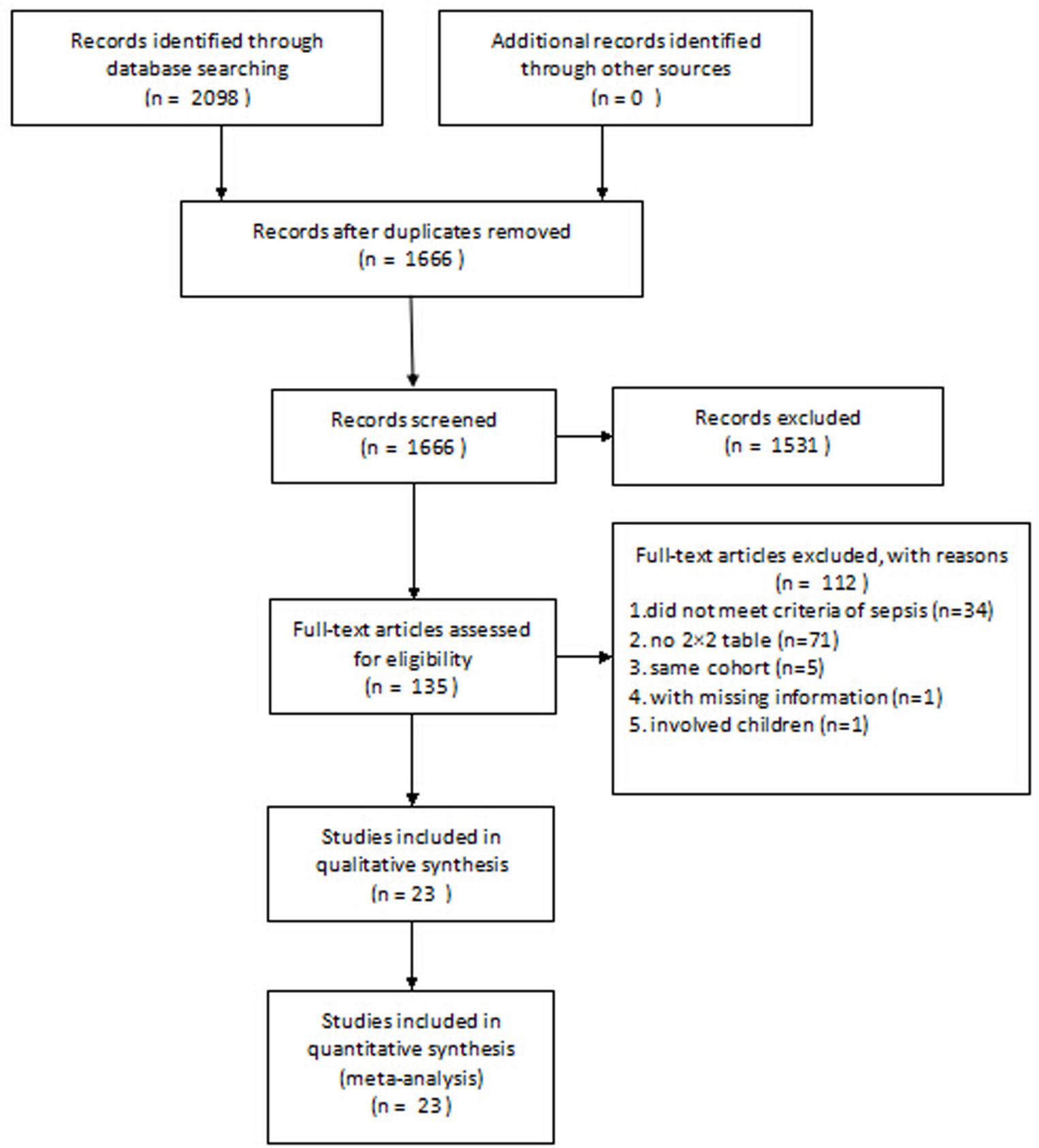

Fig 1. Flowchart of study selection.

level was associated with a higher risk of death, with RR ranging from 1.38 to 24.62. Because of the substantial heterogeneity between studies $\left(I^{2}=63.5 \%\right)$, a random-effects model was used to pool RR estimates. The pooled RR was 2.60 (95\% CI, 2.05-3.30) (Fig 3).

No statistically significant difference was observed when exploring for threshold effect (Spearman correlation coefficient $=0.062 ; P=0.820$ ). The pooled SEN and SPE were 0.76 (95\% CI, 0.67-0.82) and 0.64 (95\% CI, 0.52-0.74), respectively (S1 Fig). The PLR and NLR were 2.1 (95\% CI, 1.6-2.8) and 0.38 (95\% CI, 0.29-0.51), respectively. The DOR was 6 (95\% CI, 3-9). The overall area under the SROC curve was 0.77 (95\% CI, 0.73-0.80) (Fig 4A). 


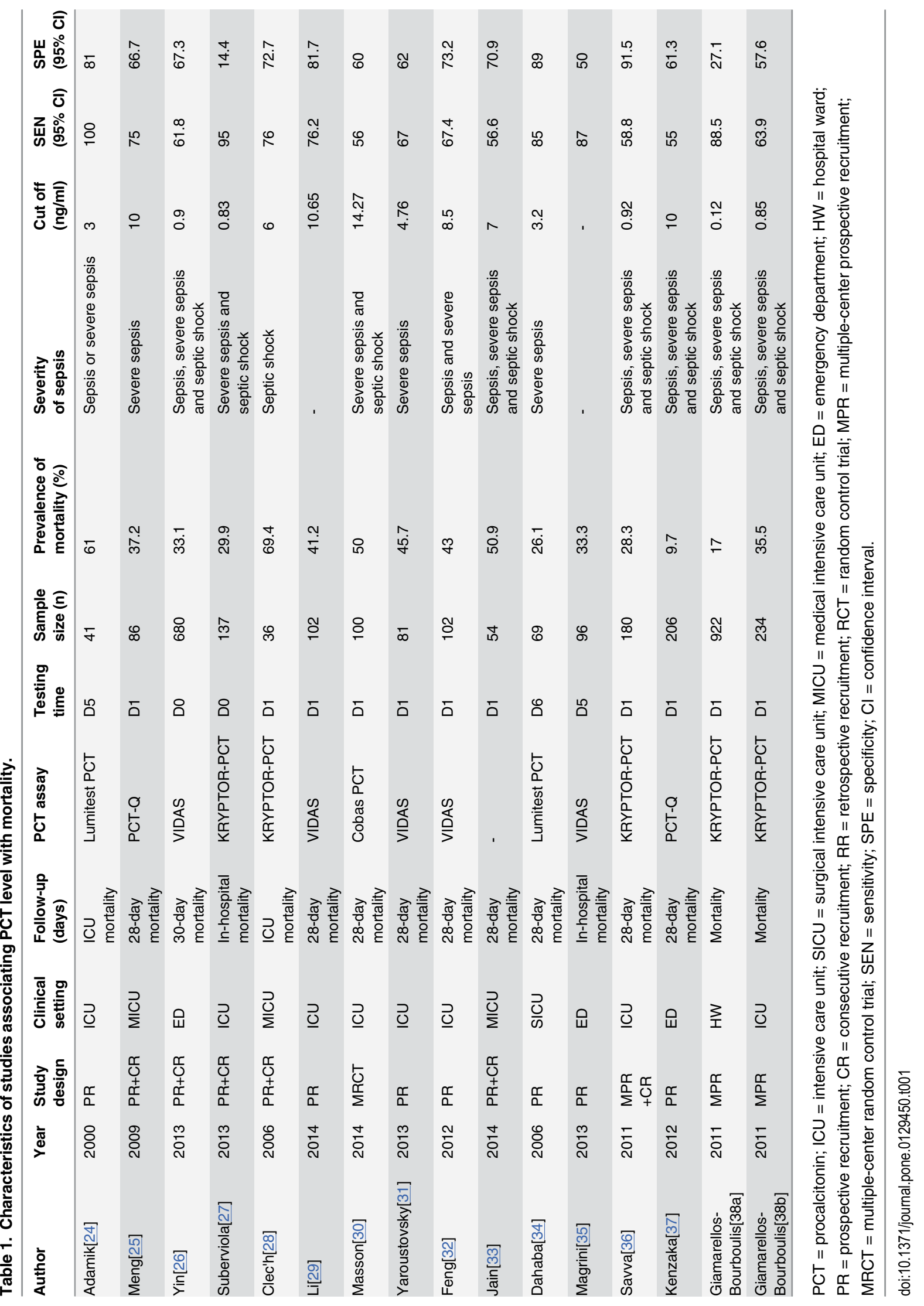


Table 2. Characteristics of studies associating PCT non-clearance with mortality.

\begin{tabular}{|c|c|c|c|c|c|c|c|c|c|c|c|}
\hline Author & Year & $\begin{array}{l}\text { Study } \\
\text { design }\end{array}$ & $\begin{array}{l}\text { Clinical } \\
\text { setting }\end{array}$ & $\begin{array}{l}\text { Follow- } \\
\text { up } \\
\text { (days) }\end{array}$ & РСТ assay & $\begin{array}{l}\text { Definition of } \\
\text { procalcitonin } \\
\text { non-clearance }\end{array}$ & $\begin{array}{l}\text { Sample } \\
\text { size }(n)\end{array}$ & $\begin{array}{l}\text { Mortality } \\
(\%)\end{array}$ & $\begin{array}{l}\text { Severity of } \\
\text { sepsis }\end{array}$ & $\begin{array}{l}\text { SEN } \\
(95 \% \\
\text { Cl) }\end{array}$ & $\begin{array}{l}\text { SPE } \\
(95 \% \\
\text { Cl) }\end{array}$ \\
\hline $\begin{array}{l}\text { Tschaikowsky } \\
\text { [39] }\end{array}$ & 2011 & $\begin{array}{l}\text { PR } \\
+C R\end{array}$ & SICU & $\begin{array}{l}\text { 28-day } \\
\text { mortality }\end{array}$ & KRYPTOR-PCT & $\begin{array}{l}\mathrm{PCT} \downarrow<50 \% \\
\text { within } 7 \mathrm{~d}\end{array}$ & 51 & 33.3 & $\begin{array}{l}\text { Severe sepsis } \\
\text { and septic } \\
\text { shock }\end{array}$ & 35.3 & 97.1 \\
\hline Schuetz[40a] & 2013 & $\begin{array}{l}\mathrm{RR} \\
+\mathrm{CR}\end{array}$ & ICU & $\begin{array}{l}\text { ICU } \\
\text { mortality }\end{array}$ & VIDAS & $\begin{array}{l}\mathrm{PCT} \downarrow<60 \% \\
\text { within } 72 \mathrm{hr}\end{array}$ & 154 & 29.2 & $\begin{array}{l}\text { Severe sepsis } \\
\text { and septic } \\
\text { shock }\end{array}$ & 60 & 67 \\
\hline Schuetz[40b] & 2013 & $\begin{array}{l}\mathrm{RR} \\
+\mathrm{CR}\end{array}$ & ICU & $\begin{array}{l}\text { ICU } \\
\text { mortality }\end{array}$ & VIDAS & $\begin{array}{l}\text { PCT } \downarrow<60 \% \\
\text { within } 72 \mathrm{hr}\end{array}$ & 102 & 17.6 & $\begin{array}{l}\text { Severe sepsis } \\
\text { and septic } \\
\text { shock }\end{array}$ & 78 & 61 \\
\hline Mat Nor[41] & 2014 & PR & ICU & $\begin{array}{l}\text { In- } \\
\text { hospital } \\
\text { mortality }\end{array}$ & KRYPTOR-PCT & $\begin{array}{l}\mathrm{PCT} \downarrow<30 \% \\
\text { within } 48 \mathrm{hr}\end{array}$ & 67 & 40.3 & Severe sepsis & 74.1 & 55 \\
\hline $\begin{array}{l}\text { Ruiz- } \\
\text { Rodriguez[42] }\end{array}$ & 2012 & PR & ICU & $\begin{array}{l}\text { ICU } \\
\text { mortality }\end{array}$ & Lumitest PCT & $\begin{array}{l}\mathrm{PCT} \downarrow<50 \% \\
\text { within } 48 \mathrm{hr}\end{array}$ & 27 & 66.7 & Septic shock & 89 & 72 \\
\hline Suberviola[43] & 2012 & PR & ICU & $\begin{array}{l}\text { In- } \\
\text { hospital } \\
\text { mortality }\end{array}$ & KRYPTOR-PCT & $\begin{array}{l}\mathrm{PCT} \downarrow<70 \% \\
\text { within } 72 \mathrm{hr}\end{array}$ & 88 & 23.9 & Septic shock & 52.6 & 94.2 \\
\hline Karlsson[44] & 2010 & $\begin{array}{l}\text { PR } \\
+C R\end{array}$ & ICU & $\begin{array}{l}\text { In- } \\
\text { hospital } \\
\text { mortality }\end{array}$ & Cobas PCT & $\begin{array}{l}\mathrm{PCT} \downarrow<50 \% \\
\text { within } 72 \mathrm{hr}\end{array}$ & 242 & 24.2 & Severe sepsis & 88.7 & 27.8 \\
\hline $\begin{array}{l}\text { Garcia de } \\
\text { Guadiana- } \\
\text { Romualdo[45] }\end{array}$ & 2014 & PR & ICU & $\begin{array}{l}\text { In- } \\
\text { hospital } \\
\text { mortality }\end{array}$ & Cobas PCT & $\begin{array}{l}\mathrm{PCT} \downarrow<40 \% \\
\text { within } 48 \mathrm{hr}\end{array}$ & 100 & 28 & $\begin{array}{l}\text { Severe sepsis } \\
\text { and septic } \\
\text { shock }\end{array}$ & 64.3 & 62.5 \\
\hline Guan[46] & 2011 & PR & ICU & Mortality & Lumitest PCT & $\begin{array}{l}\mathrm{PCT} \downarrow<25 \% \\
\text { within } 5 \mathrm{~d}\end{array}$ & 37 & 32.4 & $\begin{array}{l}\text { Sepsis, severe } \\
\text { sepsis and } \\
\text { septic shock }\end{array}$ & 100 & 100 \\
\hline
\end{tabular}

$\mathrm{PCT}$ = procalcitonin; ICU = intensive care unit; $\mathrm{SICU}=$ surgical intensive care unit; $\mathrm{ED}=$ emergency department; $\mathrm{HW}=$ hospital ward; $\mathrm{PR}=$ prospective recruitment; $\mathrm{CR}$ = consecutive recruitment; $\mathrm{RR}$ = retrospective recruitment; $\mathrm{RCT}=$ random control trial; $\mathrm{MPR}=$ multiple-center prospective recruitment; $\mathrm{MRCT}$ = multiple-center random control trial; SEN = sensitivity; SPE = specificity; $\mathrm{Cl}$ = confidence interval.

A univariate meta-regression analysis was performed to explore the sources of potential heterogeneity between studies. The year of publication, the sample size, the prevalence of mortality, the clinical setting, the assay manufacturer, the PCT testing time, the sampling method (i.e., whether studies recruited patients consecutively), and comorbidities (i.e., whether studies excluded patients with comorbidities potentially linked to PCT levels) were included in the analysis. The results indicated that only PCT testing time was statistically significant for heterogeneity $(P=0.020)$. The initial PCT level was of limited prognostic value in patients with sepsis. Subgroup analyses are shown in Table 3.

Analysis of the effect of PCT non-clearance on mortality. Nine studies [39-46] with 868 patients were included in this group. Because the heterogeneity between studies was acceptable $\left(I^{2}=37.9 \%\right)$, a fixed-effects model was used to pool RR estimates. The pooled RR for mortality was 3.05 (95\% CI, 2.35-3.95) (Fig 5).

No statistically significant differences were observed when exploring the threshold effect (Spearman correlation coefficient $=0.133 ; P=0.732$ ). The pooled SEN and SPE were 0.72 (95\% CI, 0.58-0.82) and 0.77 (95\% CI, 0.55-0.90), respectively (S2 Fig). The PLR and NLR were 3.1 (95\% CI, 1.5-6.3) and 0.37 (95\% CI, 0.25-0.55), respectively. The DOR was 8 (95\% CI, 3-22). The overall area under the SROC curve was 0.79 (95\% CI, 0.75-0.83) (Fig 4B). 

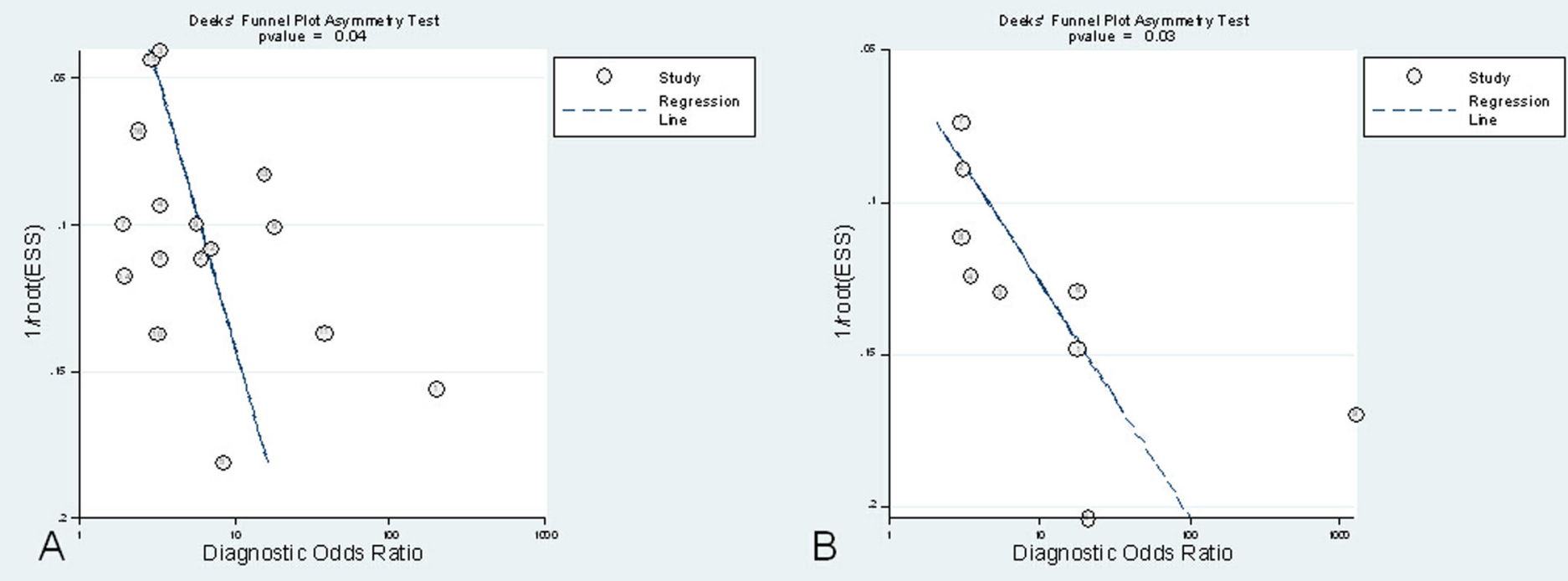

Fig 2. Deek's funnel plot asymmetry test for publication bias (A. For single procalcitonin concentration; B. For procalcitonin non-clearance). Potential publication bias exists $(\mathrm{P}<0.05)$.

doi:10.1371/journal.pone.0129450.g002

\section{Discussion}

In this meta-analysis, we first determined that both single PCT concentrations and PCT nonclearance were strongly associated with all-cause mortality in septic patients. Our evidence may confer additional information for the clinical use of PCT apart from diagnosing infection [47] and helping guide therapeutic decision-making [48].

We further identified that PCT non-clearance could predict sepsis mortality. The pooled RR for mortality was 3.05 ( $95 \%$ CI, 2.35-3.95). The overall area under the SROC curve was 0.79 (95\% CI, 0.75-0.83). We evaluated the prognostic performance of PCT, and the results showed that the diagnostic performance of both a single PCT concentration and PCT clearance is moderate for predicting sepsis mortality.

The implementation of the appropriate therapeutic interventions appeared to be more significant when initiated rapidly at the time of the patient's arrival. Delayed resuscitation has been found to be significantly associated with a risk of death [49-50]. The prognostic value of biomarkers have been widely investigated in other meta-analyses [51, 52]. However, those meta-analyses were not immune to unexplained heterogeneity and had a limited number of patients. In our research, PCT non-clearance has emerged as an ideal index to predict prognosis in sepsis. The overall area under the SROC curve was 0.79 (95\% CI, 0.75-0.83), which was greater than the results of published meta-analyses of troponins [51] and lactate clearance [52]. In addition, the heterogeneity between studies was acceptable $\left(I^{2}=37.9 \%\right)$, which showed our results were reliable. The initial PCT level was of limited prognostic value in patients with sepsis. The pooled SEN and SPE were 0.72 (95\% CI, 0.63-0.79) and 0.62 (95\% CI, 0.49-0.73), respectively. The overall area under the SROC curve was only 0.73 (95\% CI, 0.69-0.77).

Our study has several limitations. First, we failed to assess the diagnostic accuracy of PCT for predicting death in ED patients because of the limited number of available studies. Thus, our results probably cannot be applied to ED patients. Second, also owing to the limited number of available studies, we could not perform subgroup analyses based on different admission 
Study

ID
RR $(95 \% \mathrm{Cl}) \quad$ Weight

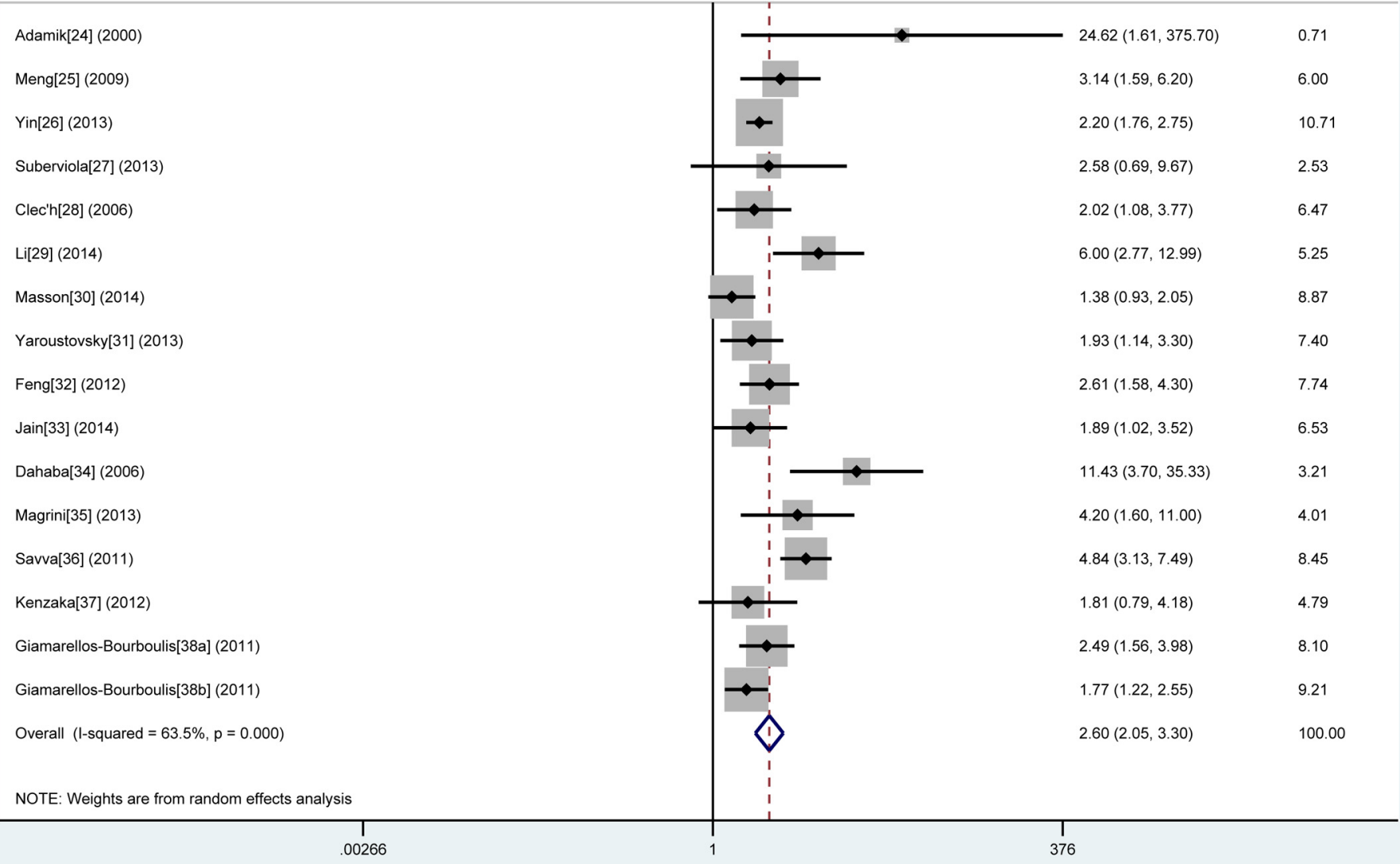

Fig 3. Forest plot of procalcitonin concentration to predict mortality in sepsis. The overall pooled $\mathrm{RR}$ was 2.60 (95\% $\mathrm{Cl}, 2.05-3.30)$.

doi:10.1371/journal.pone.0129450.g003

categories and sites of infection. Third, we could not determine the optimized cut-off value because we failed to obtain the raw data (the procalcitonin level in each patient) from each original article to map out the ROC curve. We have tried to contact the corresponding authors to obtain the data, but has been difficult to acquire the procalcitonin level of each patients in each trail. And also, we could not conclude the optimal definition of PCT non-clearance required for accurate risk assessment.

Sepsis is a complex pathophysiological process rather than a specific syndrome. Thus far, no ideal biomarker has demonstrated sufficient SEN and SPE to provide clinical utility for predicting sepsis mortality [53]. Clinicians need to provide a more comprehensive evaluation of individual patient conditions. Future studies should highlight the combination of procalcitonin with other clinical indexes as part of an overall assessment of sepsis prognosis rather than adopting a biomarker-based approach to the prediction of sepsis mortality. The combination of PCT and other clinical indexes may provide valuable information to assist clinicians in identifying patients at high risk of dying from sepsis. Several studies $[8,22]$ showed that PCT 

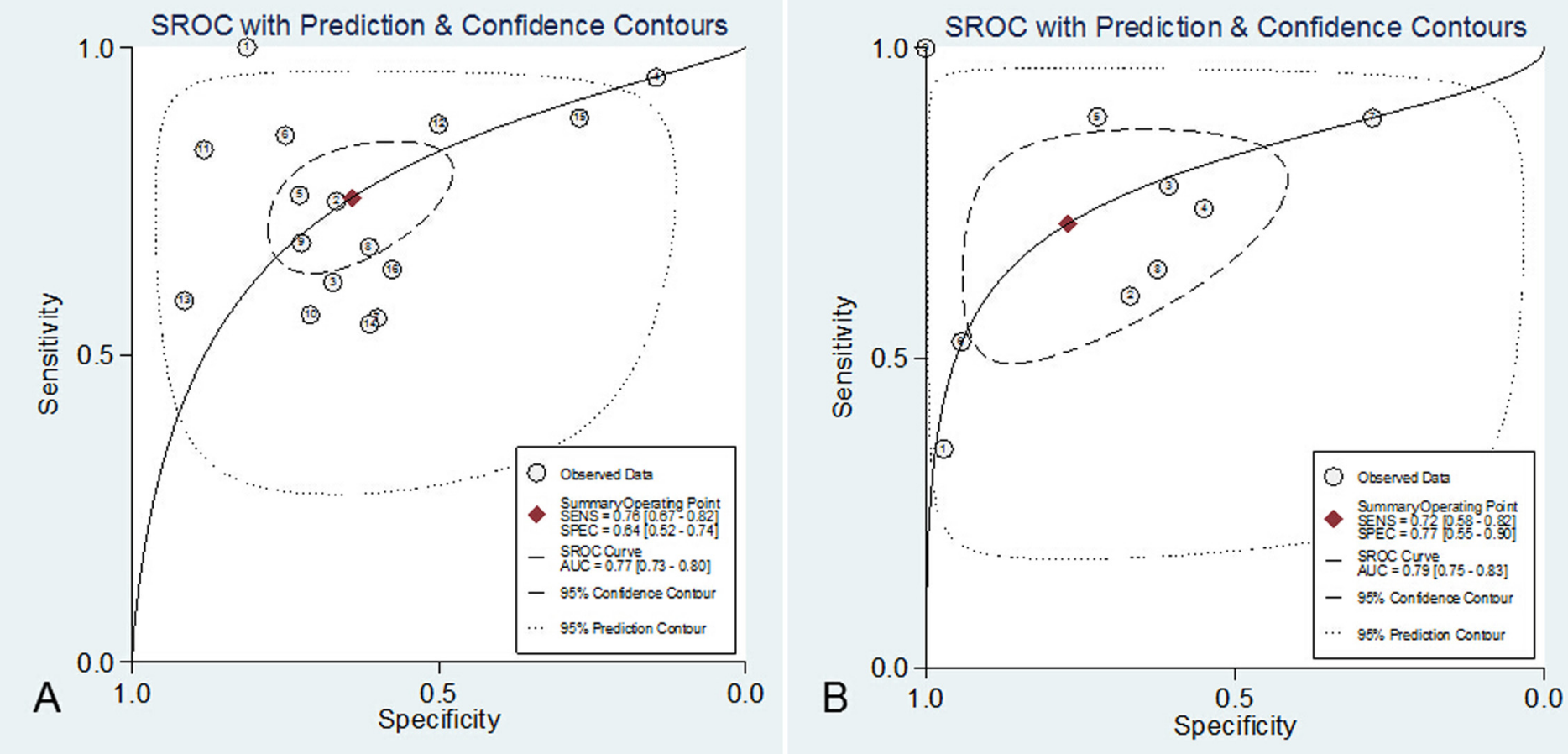

Fig 4. Summary receiver operating characteristic graph of the included studies (A. For single procalcitonin concentration; B. For procalcitonin nonclearance).

doi:10.1371/journal.pone.0129450.g004

concentrations were related to APACHEII and SOFA scores. Of the studies included in this meta-analysis, Suberviola [20] demonstrated an improved prognostic value when PCT was combined with the APACHEII score. Further studies should be performed to help determine the optimal cut-off point and definition for PCT non-clearance required for accurate risk assessment.

Table 3. Subgroup analysis.

\begin{tabular}{|c|c|c|c|c|c|c|c|c|c|c|}
\hline Variables & $\begin{array}{l}\text { No. of } \\
\text { studies }\end{array}$ & $\begin{array}{l}\text { No. of } \\
\text { patients }\end{array}$ & $\begin{array}{l}\text { SEN } \\
(95 \% \mathrm{Cl})\end{array}$ & $\begin{array}{l}\text { SPE } \\
(95 \% \mathrm{Cl})\end{array}$ & $\begin{array}{l}\text { DOR } \\
(95 \% \mathrm{Cl})\end{array}$ & $\begin{array}{l}\text { PLR } \\
\text { (95\% } \\
\text { Cl) }\end{array}$ & $\begin{array}{l}\text { NLR } \\
(95 \% \mathrm{Cl})\end{array}$ & $\begin{array}{l}\text { AUC } \\
(95 \% \mathrm{Cl})\end{array}$ & $\begin{array}{l}\text { Test for } \\
\text { heterogeneity } \\
\text { (I2) }\end{array}$ & $\begin{array}{l}\text { Deek's funnel } \\
\text { test ( } p \text { value) }\end{array}$ \\
\hline Overall & 16 & 3126 & $\begin{array}{l}0.76 \\
(0.67- \\
0.82)\end{array}$ & $\begin{array}{l}0.64 \\
(0.52- \\
0.74)\end{array}$ & $6(3-9)$ & $\begin{array}{l}2.1(1.6- \\
2.8)\end{array}$ & $\begin{array}{l}0.38 \\
(0.29- \\
0.51)\end{array}$ & $\begin{array}{l}0.77 \\
(0.73- \\
0.80)\end{array}$ & 63.5 & 0.04 \\
\hline $\begin{array}{l}\text { Initial PCT } \\
\text { concentration }\end{array}$ & 13 & 2920 & $\begin{array}{l}0.72 \\
(0.63- \\
0.79)\end{array}$ & $\begin{array}{l}0.62 \\
(0.49- \\
0.73)\end{array}$ & $4(3-6)$ & $\begin{array}{l}1.9(1.4- \\
2.4)\end{array}$ & $\begin{array}{l}0.46 \\
(0.37- \\
0.56)\end{array}$ & $\begin{array}{l}0.73 \\
(0.69- \\
0.77)\end{array}$ & 57.5 & 0.29 \\
\hline ICU patients & 12 & 1222 & $\begin{array}{l}0.76 \\
(0.65- \\
0.84)\end{array}$ & $\begin{array}{l}0.69 \\
(0.55- \\
0.80)\end{array}$ & $7(4-13)$ & $\begin{array}{l}2.4(1.7- \\
3.6)\end{array}$ & $\begin{array}{l}0.35 \\
(0.24- \\
0.51)\end{array}$ & $\begin{array}{l}0.79 \\
(0.75- \\
0.82)\end{array}$ & 72.1 & 0.12 \\
\hline $\begin{array}{l}\text { Severe sepsis/ } \\
\text { septic shock }\end{array}$ & 6 & 509 & $\begin{array}{l}0.77 \\
(0.62- \\
0.87)\end{array}$ & $\begin{array}{l}0.61 \\
(0.38- \\
0.80)\end{array}$ & $5(2-11)$ & $\begin{array}{l}1.9(1.2- \\
3.2)\end{array}$ & $\begin{array}{l}0.39 \\
(0.25- \\
0.61)\end{array}$ & $\begin{array}{l}0.76 \\
(0.73- \\
0.80)\end{array}$ & 67.3 & 0.17 \\
\hline
\end{tabular}

$\mathrm{PCT}$ = procalcitonin; ICU = intensive care unit; $\mathrm{ED}=$ emergency department; SEN = sensitivity; SPE = specificity; $\mathrm{DOR}=$ diagnostic odds ratio; $\mathrm{PLR}=$ positive likelihood ratio; NLR = negative likelihood ratio; $\mathrm{AUC}=$ area under the curve; $\mathrm{Cl}=$ confidence interval. 
Study

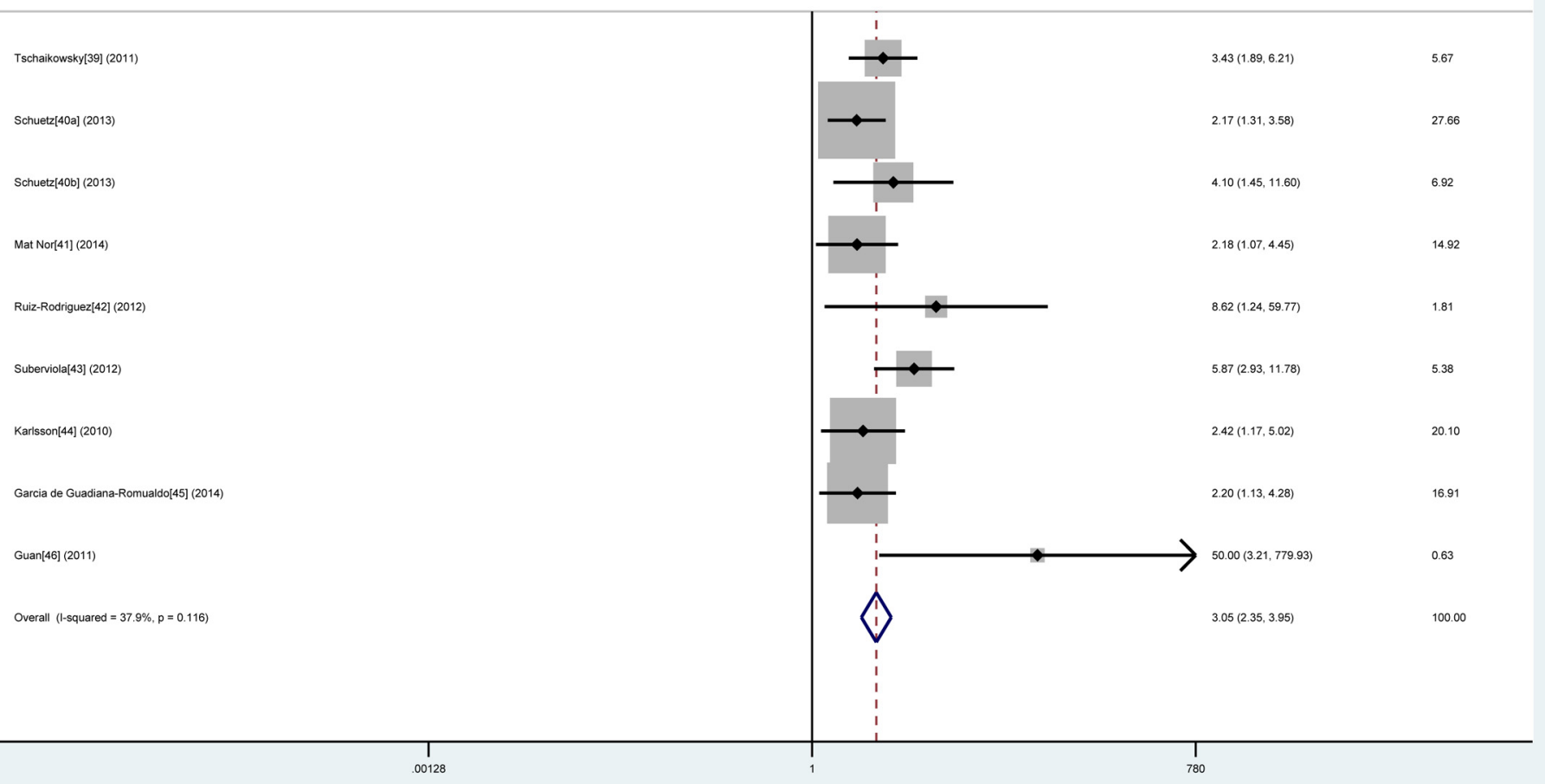

Fig 5. Forest plot of procalcitonin non-clearance to predict mortality in sepsis. The overall pooled $\mathrm{RR}$ was $3.05(95 \% \mathrm{Cl}, 2.35-3.95)$.

\section{Conclusions}

We found that elevated PCT levels and PCT non-clearance were associated with a higher risk of death in patients with sepsis. However, PCT may not be useful as a single index for assessing prognosis because of its moderate diagnostic accuracy, though it may be useful in combination with patients' overall conditions and other clinical indexes. Further studies are needed to define the optimal cut-off point and a definition of PCT non-clearance required for accurate risk assessment.

\section{Supporting Information}

S1 File. PRISMA 2009 Flow Diagram.

(DOC)

S2 File. PRISMA 2009 checklist.

(DOC)

S3 File. AJE_Edited_XJQYC7J3_modified_manuscript_Prognosis_value_of_procalcitonin_in_sepsis_a_systematic_review_and_meta_analysis_SE_QCE.

(DOC) 
S4 File. Collection of tables in the manuscript.

(DOC)

S1 Fig. Forest plot of the sensitivity and specificity of procalcitonin concentration for predicting mortality in sepsis.

(TIF)

S2 Fig. Forrest plot of the sensitivity and specificity of procalcitonin non-clearance for predicting mortality in sepsis.

(TIF)

\section{Acknowledgments}

We sincerely thank all authors who provided published data for our meta-analysis.

\section{Author Contributions}

Conceived and designed the experiments: LX LS. Performed the experiments: DL LS. Analyzed the data: DL LS. Contributed reagents/materials/analysis tools: DL LS GH PY. Wrote the paper: DL.

\section{References}

1. Czura CJ. "Merinoff Symposium 2010: sepsis"-speaking with one voice. Mol Med. 2011; 17: 2-3. doi: 10.2119/molmed.2010.00001.commentary PMID: 21246163

2. Dombrovskiy VY, Martin AA, Sunderram J, Paz HL. Rapid increase inhospitalization and mortality rates for severe sepsis in the United States: a trend analysis from 1993 to 2003. Crit Care Med. 2007; 35: 1244-1250. PMID: 17414736

3. Iskander KN, Osuchowski MF, Stearns-Kurosawa DJ, Kurosawa S, Stepien D, Valentine C, et al. Sepsis: Multiple Abnormalities, Heterogeneous Responses, and Evolving Understanding. Physiol Rev. 2013; 93: 1247-1288. doi: 10.1152/physrev.00037.2012 PMID: 23899564

4. Kiguchi T, Nakamori Y, Yamakawa K, Kitayama J, Wada D, Ogawa Y, et al. Maximal chemiluminescent intensity in response to lipopolysaccharide assessed by endotoxin activity assay on admission day predicts mortality in patients with sepsis. Crit Care Med. 2013; 43: 1443-9.

5. Gründler K, Angstwurm M, Hilge R, Baumann P, Annecke T, Crispin A, et al. Platelet mitochondrial membrane depolarization reflects disease severity in patients with sepsis and correlates with clinical outcome. Crit Care. 2014; 18: R31. doi: 10.1186/cc13724 PMID: 24521521

6. Behnes M, Bertsch T, Lepiorz D, Lang S, Trinkmann F, Brueckmann M, et al. Diagnostic and prognostic utility of soluble CD 14 subtype (presepsin) for severe sepsis and septic shock during the first week of intensive care treatment. Crit Care; 2014; 14: 507.

7. Akpinar S, Rollas K, Alagöz A, Seğmen F, Sipit T. Performance evaluation of MR-proadrenomedullin and other scoring systems in severe sepsis with pneumonia. J Thorac Dis. 2014; 6: 921-9. doi: 10. 3978/j.issn.2072-1439.2014.06.42 PMID: 25093088

8. Vassiliou AG, Mastora Z, Orfanos SE, Jahaj E, Maniatis NA, Koutsoukou A, et al. Elevated biomarkers of endothelial dysfunction/activation at ICU admission are associated with sepsis development. Cytokine. 2014; 69: 240-7. doi: 10.1016/j.cyto.2014.06.010 PMID: 25016133

9. Krüger S, Ewig S, Marre R, Papassotiriou J, Richter K, von Baum H, et al. Procalcitonin predicts patients at low risk of death from community-acquired pneumonia across all CRB-65 classes. Eur Respir J. 2008; 31(2): 349-55 PMID: 17959641

10. Huang DT, Weissfeld LA, Kellum JA, Yealy DM, Kong L, Martino M, et al. Risk Prediction with Procalcitonin and Clinical Rules in Community-Acquired Pneumonia. Ann Emerg Med. 2008; 52(1): 48-58.e2 doi: 10.1016/j.annemergmed.2008.01.003 PMID: 18342993

11. Hillas G, Vassilakopoulos $T$, Plantza P, Rasidakis A, Bakakos P. C-reactive protein and procalcitonin as predictors of survival and septic shock in ventilator-associated pneumonia. Eur Respir J. 2010; 35 (4): 805-11 doi: 10.1183/09031936.00051309 PMID: 19717486

12. Garnacho-Montero J, Huici-Moreno MJ, Gutiérrez-Pizarraya A, López I, Márquez-Vácaro JA, Macher $\mathrm{H}$, et al. Prognostic and diagnostic value of eosinopenia, C-reactive protein, procalcitonin, and 
circulating cell-free DNA in critically III patients admitted with suspicion of sepsis. Crit Care. 2014; 18 : R116. doi: 10.1186/cc13908 PMID: 24903083

13. Ulla M, Pizzolato E, Lucchiari M, Loiacono M, Soardo F, Forno D, et al. Diagnostic and prognostic value of presepsin in the management of sepsis in the emergency department: a multicenter prospective study. Crit Care. 2013; 17: R168. doi: 10.1186/cc12847 PMID: 23899120

14. Levy MM, Fink MP, Marshall JC, Abraham E, Angus D, Cook D, et al. 2001 SCCM/ESICM/ACCP/ATS/ SIS International Sepsis Definitions Conference. Intensive Care Med. 2003; 29:530-8. PMID: 12664219

15. American College of Chest Physicians/Society of Critical Care Medicine Consensus Conference: definitions for sepsis and organ failure and guidelines for the use of innovative therapies in sepsis. Crit Care. 1992; 20: 864-874. PMID: 1597042

16. Whiting P, Rutjes AW, Reitsma JB, Bossuyt PM, Kleijnen J. The development of QUADAS: a tool for the quality assessment of studies of diagnostic accuracy included in systematic reviews. BMC Med Res Methodol. 2003; 3: 25. PMID: 14606960

17. Higgins JP, Thompson SG, Deeks JJ, Altman DG. Measuring inconsistency in meta-analyses. British Medical Journal. 2003; 327(7414): 557. PMID: 12958120

18. DerSimonian R, Laird N. Meta-analysis in clinical trials. Control Clin Trials. 1986; 7: 177-188 PMID: 3802833

19. Higgins JP, Thompson SG. Quantifying heterogeneity in a meta-analysis. Stat Med. 2002; 21: 15391558 PMID: 12111919

20. Cucherat M, Boissel JP, Leizorovicz A, Haugh MC. EasyMA: a program for the meta-analysis of clinical trials. Comput Methods Programs Biomed. 1997; 53: 187-190 PMID: 9230453

21. Whiting P, Rutjes AW, Reitsma JB, Bossuyt PM, Kleijnen J. The development of QUADAS: a tool for the quality assessment of studies of diagnostic accuracy included in systematic reviews. BMC Med Res Methodol. 2003; 3: 25. PMID: 14606960

22. Reitsma JB, Glas AS, Rutjes AW, Scholten RJ, Bossuyt PM, Zwinderman AH. Bivariate analysis of sensitivity and specificity produces informative summary measures in diagnostic reviews. J Clin Epidemiol. 2005; 58: 982-990. PMID: 16168343

23. Moses LE, Shapiro D, Littenberg B. Combining independent studies of a diagnostic test into a summary ROC curve: data-analytic approaches and some additional considerations. Stat Med. 1993; 12: 12931316. PMID: 8210827

24. Adamik B, Kübler-Kielb J, Golebiowska B, Gamian A, Kübler A. Effect of sepsis and cardiac surgery with cardiopulmonary bypass on plasma level of nitric oxide metabolites, neopterin, and procalcitonin: correlation with mortality and postoperative complications. Intensive Care Med. 2000; 26: 1259-67. PMID: 11089751

25. Meng FS, Su L, Tang YQ, Wen Q, Liu YS, Liu ZF, et al. Serum procalcitonin at the time of admission to the ICU as a predictor of short-term mortality. Clin Biochem. 2009; 42: 1025-31. doi: 10.1016/j. clinbiochem.2009.03.012 PMID: 19324026

26. Yin Q, Liu B, Chen Y, Zhao Y, Li C. The role of soluble thrombomodulin in the risk stratification and prognosis evaluation of septic patients in the emergency department. Thromb Res. 2013; 132: 471-6. doi: 10.1016/j.thromres.2013.08.011 PMID: 24035044

27. Suberviola B, Castellanos-Ortega A, Ruiz Ruiz A, Lopez-Hoyos M, Santibañez M. Hospital mortality prognostication in sepsis using the new biomarkers suPAR and proADM in a single determination on ICU admission. Intensive Care Med. 2013; 39: 1945-52. doi: 10.1007/s00134-013-3056-z PMID: 23949703

28. Clec'h C, Fosse JP, Karoubi P, Vincent F, Chouahi I, Hamza L, et al. Differential diagnostic value of procalcitonin in surgical and medical patients with septic shock Crit Care Med. 2006; 34: 102-7. PMID: 16374163

29. Li Z, Wang H, Liu J, Chen B, Li G. Serum soluble triggering receptor expressed on myeloid cells-1 and procalcitonin can reflect sepsis severity and predict prognosis: a prospective cohort study. Mediators Inflamm. 2014; 2014: 641039 doi: 10.1155/2014/641039 PMID: 24672147

30. Masson S, Caironi P, Spanuth E, Thomae R, Panigada M, Sangiorgi G, et al. Presepsin (soluble CD14 subtype) and procalcitonin levels for mortality prediction in sepsis: data from the Albumin Italian Outcome Sepsis trial. Crit Care. 2014; 18: R6. doi: 10.1186/cc13183 PMID: 24393424

31. Yaroustovsky M, Plyushch M, Popov D, Samsonova N, Abramyan M, Popok Z, et al. Prognostic value of endotoxin activity assay in patients with severe sepsis after cardiac surgery. J Inflamm (Lond). 2014; 10: 8. 
32. Feng L, Zhou X, Su LX, Feng D, Jia YH, Xie LX. Clinical significance of soluble hemoglobin scavenger receptor CD163 (sCD163) in sepsis, a prospective study. PLoS One. 2012; 7: e38400. doi: 10.1371/ journal.pone.0038400 PMID: 22911680

33. Jain S, Sinha S, Sharma SK, Samantaray JC, Aggrawal P, Vikram NK, et al. Procalcitonin as a prognostic marker for sepsis: a prospective observational study. BMC Res Notes. 2014; 7: 458-458. doi: 10.1186/1756-0500-7-458 PMID: 25034373

34. Dahaba AA, Hagara B, Fall A, Rehak PH, List WF, Metzler H, et al. Procalcitonin for early prediction of survival outcome in postoperative critically ill patients with severe sepsis. British Journal of Anaesthesia. 2006; 97(4): 503-508. PMID: 16849384

35. Magrini L, Travaglino F, Marino R, Ferri E, De Berardinis B, Cardelli P, et al. Procalcitonin variations after Emergency Department admission are highly predictive of hospital mortality in patients with acute infectious diseases. European Review for Medical and Pharmacological Sciences. 2013; 17: 133-142. PMID: 23436675

36. Savva A, Raftogiannis M, Baziaka F, Routsi C, Antonopoulou A, Koutoukas $P$, et al. Soluble urokinase plasminogen activator receptor (suPAR) for assessment of disease severity in ventilator-associated pneumonia and sepsis. Journal of Infection. 2011; 63(5): 344-350. doi: 10.1016/j.jinf.2011.07.016 PMID: 21839112

37. Kenzaka T, Okayama M, Kuroki S, Fukui M, Yahata S, Hayashi H, et al. Use of a semiquantitative procalcitonin kit for evaluating severity and predicting mortality in patients with sepsis. International journal of general medicine. 2012; 5: 483-488. doi: 10.2147/IJGM.S32758 PMID: 22701089

38. Giamarellos-Bourboulis EJ, Tsangaris I, Kanni T, Mouktaroudi M, Pantelidou I, Adamis G, et al. Procalcitonin as an early indicator of outcome in sepsis: a prospective observational study. Journal of Hospital Infection. 2011; 77(1): 58-63. doi: 10.1016/j.jhin.2010.07.026 PMID: 21131099

39. Tschaikowsky K, Hedwig-Geissing M, Braun GG, Radespiel-Troeger M. Predictive value of procalcitonin, interleukin-6, and C-reactive protein for survival in postoperative patients with severe sepsis. J Crit Care. 2011; 26(1): 54-64. doi: 10.1016/j.jcrc.2010.04.011 PMID: 20646905

40. Schuetz P, Maurer P, Punjabi V, Desai A, Amin DN, Gluck E. Procalcitonin decrease over 72 hours in US critical care units predicts fatal outcome in sepsis patients. Crit Care. 2013; 17(3): R115. doi: 10. 1186/cc12787 PMID: 23787145

41. Mat Nor MB, Md Ralib A. Procalcitonin clearance for early prediction of survival in critically ill patients with severe sepsis. Crit Care Res Pract. 2014; 2014: 819034. doi: 10.1155/2014/819034 PMID: 24719759

42. Ruiz-Rodríguez JC, Caballero J, Ruiz-Sanmartin A, Ribas VJ, Pérez M, Bóveda JL, et al. Usefulness of procalcitonin clearance as a prognostic biomarker in septic shock. A prospective pilot study. Medicina Intensiva. 2014; 36(7): 475-480.

43. Suberviola B, Castellanos-Ortega A, González-Castro A, García-Astudillo LA, Fernández-Miret B. Prognostic value of procalcitonin, $C$-reactive protein and leukocytes in septic shock. Medicina Intensiva. 2012; 36(3): 177-184. doi: 10.1016/j.medin.2011.09.008 PMID: 22055776

44. Karlsson S, Heikkinen M, Pettilä V, Alila S, Väisänen S, Pulkki K, et al. Predictive value of procalcitonin decrease in patients with severe sepsis: A prospective observational study. Crit Care. 2010; 14(6): R205 doi: 10.1186/cc9327 PMID: 21078153

45. García de Guadiana-Romualdo LM, Rebollo-Acebes S, Esteban-Torrella $P$, Jiménez-Sánchez R, Hernando-Holgado A, Ortín-Freire A, et al. Prognostic value of lipopolysaccharide binding protein and procalcitonin in patients with severe sepsis and septic shock admitted to intensive care. Med Intensiva. 2015; 39(4): 207-212. doi: 10.1016/j.medin.2014.04.005 PMID: 24953001

46. Guan J, Lin Z, Lue H. Dynamic change of procalcitonin, rather than concentration itself, is predictive of survival in septic shock patients when beyond $10 \mathrm{ng} / \mathrm{mL}$. Shock. 2011; 36(6): 570-574. doi: 10.1097/ SHK.0b013e31823533f9 PMID: 21937947

47. Wacker C, Prkno A, Brunkhorst FM, Schlattmann P. Procalcitonin as a diagnostic marker for sepsis: a systematic review and meta-analysis. Lancet Infect Dis. 2014; 13(5): 426-35.

48. Jensen JU, Hein L, Lundgren B, Bestle MH, Mohr TT, Andersen MH, et al. Procalcitonin And Survival Study (PASS) Group: Procalcitonin-guided interventions against infections to increase early appropriate antibiotics and improve survival in the intensive care unit: a randomized trial. Crit Care Med. 2011; 39: 2048-2058. doi: 10.1097/CCM.0b013e31821e8791 PMID: 21572328

49. Ferrer R, Artigas A, Levy MM, Blanco J, González-Díaz G, Garnacho-Montero J, et al. Improvement in process of care and outcome after a multicenter severe sepsis educational program in Spain. JAMA. 2008; 299: 2294-2303. doi: 10.1001/jama.299.19.2294 PMID: 18492971

50. Kiers HD, Griesdale DE, Litchfield A, Reynolds S, Gibney RT, Chittock D, et al. Effect of early achievement of physiologic resuscitation goals in septic patients admitted from the ward on the kidneys. J Crit Care. 2010; 24: 563-9. 
51. Bessière F, Khenifer S, Dubourg J, Durieu I, Lega JC. Prognostic value of troponins in sepsis: a metaanalysis. Intensive Care Med. 2013; 39(7): 1181-9 doi: 10.1007/s00134-013-2902-3 PMID: 23595497

52. Zhang Z, Xu X. Lactate Clearance Is a Useful Biomarker for the Prediction of All-Cause Mortality in Critically III Patients: A Systematic Review and Meta-Analysis. Crit Care Med. 2014; 42(9): 2118-25 doi: 10.1097/CCM.0000000000000405 PMID: 24797375

53. Sandquist $M$, Wong HR. Biomarkers of sepsis and their potential value in diagnosis, prognosis and treatment. Expert Rev Clin Immunol. 2014; 21: 1-8. 